\title{
Encapsulated specialty oils commercialized in São Paulo state, Brazil: evaluation of identity (fatty acid profile) and compliance of fatty acids and Vitamin E contents with nutrition labeling
}

\author{
Óleos especiais encapsulados comercializados no Estado de São Paulo, Brasil: avaliação da identidade \\ (perfil de ácidos graxos) e da adequação do conteúdo de ácidos graxos e vitamina E da informação nutricional
}

\section{Karen HIRASHIMA ${ }^{1}$, Simone Alves da SILVA ${ }^{1}$, Miriam Solange Fernandes CARUSO ${ }^{1}$, Sabria AUED-PIMENTEL ${ }^{1 \star}$}

\begin{abstract}
Encapsulated specialty oils commercialized in São Paulo state, Brazil, were evaluated for their identity (fatty acids profile) and compliance with nutrition labeling (fatty acids and Vitamin E (alpha tocopherol) contents). Twenty one samples [flaxseed oil (6), evening primrose (5), safflower (8), borage (1), and black currant (1)] purchased from local markets or collected by the health surveillance agency were analyzed. The fatty acids and vitamin E contents were analyzed by gas chromatography with flame ionization detector and liquid chromatography with UV detector, respectively. Nine samples were adulterated (5 samples of safflower oil, 3 of flaxseed oil, and one of evening primrose). Among them, 3 flaxseed and 2 safflower oil samples were probably adulterated by the addition of soybean oil. Conjugated linoleic acid (CLA) was found in two safflower oils samples although the sale of oils with conjugated linoleic acid (CLA) is not permitted by the National Health Surveillance Agency in Brazil (ANVISA). Only two samples presented all values in compliance with nutrition labeling (one safflower oil sample and one borage oil sample). The results show that a continuous monitoring of encapsulated specialty oils commercialized in Brazil is necessary including a greater number of samples and sanitary surveillance.

Keywords: specialty oils; functional food; legislation.
\end{abstract}

\section{Resumo}

Óleos especiais em cápsulas, comercializados no Estado de São Paulo, Brasil, foram avaliados quanto à identidade, pelo perfil de ácidos graxos, e à conformidade das informações declaradas na rotulagem nutricional (conteúdo de ácidos graxos e vitamina E, alfa tocoferol). Foram analisadas 21 amostras [linhaça (6), prímula (5), cártamo (8), borage (1) e groselhas negras (1)], adquiridas no comércio ou colhidas pela vigilância sanitária. Os ácidos graxos e a vitamina $\mathrm{E}$ foram analisados por cromatografia gasosa com detector de ionização de chama e cromatografia líquida com detector UV, respectivamente. Nove amostras estavam adulteradas ( 5 de cártamo, 3 de linhaça e uma de prímula). Entre as adulteradas, 3 de linhaça e 2 de cártamo tinham, provavelmente, adição de óleo de soja. Ácido linoleico conjugado (CLA) foi encontrado em duas amostras denominadas de óleo de cártamo, apesar da Agência Nacional de Vigilância Sanitária (ANVISA) não autorizar a venda de óleos contendo CLA no Brasil. Somente duas amostras apresentaram todos os componentes analisados de acordo com o declarado na rotulagem (uma de óleo de linhaça e outra de borage). Os resultados indicam a necessidade de um monitoramento contínuo dos óleos especiais encapsulados comercializados no Brasil, incluindo um número maior de amostras e em conjunto com a vigilância sanitária.

Palavras-chave: óleos especiais; alimento funcional; legislação.

\section{Introduction}

Among the functional foods, specialty oils contain biologically active lipids such as essential fatty acids and vitamin E, which help to promote health and prevent diseases. Essential fatty acids are not synthesised endogenously and must be obtained from the diet. The deficiency of these components in the body can compromise mental development, and cause chronic and acute metabolic disorders (SIMPOULOS, 2006; LIMA et al., 2007). Vitamin E (alpha-tocopherol) has antioxidant properties and prevents the chain reactions induced by free radicals in biological membranes (SOUZA; SOUZANETO; MAIA, 2003).

Vegetable oils, such as flaxseed and safflower, are sources of essential fatty acids like alpha linolenic $(18: 3$ cis $9,12,15)$ and linoleic $(18: 2$ cis 9,12$)$, which belong to the omega 3 and omega 6 series, respectively. Monounsaturated fatty acids (MUFA) are found in vegetable oils such as olive oil (CODEX..., 2005), and studies have demonstrated that diets rich in oleic acid (18:1 cis 9) reduce plasma concentrations of the low density lipoprotein (LDL) and protect them from oxidation. The oxidative modification of LDL is a determinant risk factor for atherosclerosis (KATSIKI; MANES, 2009; YOSHIDA; KISUGI, 2010).

Potential beneficial effects of virgin coconut oil on weight control and glucose as well as lipid metabolism have been attributed to the high content of medium-chain triglyceride.

Received 16/2/2012

Accepted 4/11/2012 (005582)

${ }^{1}$ Núcleo de Química, Física e Sensorial, Centro de Alimentos, Instituto Adolfo Lutz - IAL, Av. Doutor Arnaldo, 355, CEP 01246-902, São Paulo, SP, Brasil,

e-mail:spimente@ial.sp.gov.br

${ }^{*}$ Corresponding author 
In addition, one of the roles of biologically active polyphenol components is to prevent LDL oxidation (NEVIN; RAJAMOHA, 2004; MARTEN; PFEUFFER; SCHREZENMEIR, 2006).

Borage seed oil (Borago officinale) and evening primrose (Oenothera biennis), from Boraginaceae and Onagraceae families, contain high quantities of gamma-linolenic fatty acid (GLA), omega-6 series, which is a precursor of essential fatty acids. There are several studies that positively correlate the intake of gamma-linolenic acid to the treatment of various diseases such as dermatitis, premenstrual syndrome, hypertension, stress, multiple sclerosis, diabetes, and cancers among others (AUED-PIMENTEL; CARUSO, 1999; HOMYEH et al., 2002; PHAM; VANG; ZIBOH, 2006; KONG et al., 2009; FOSTER; HARDY; ALANY, 2010).

In the Brazilian market, these specialty oils are high valueadded products sold in capsules.

The Brazilian National Health Surveillance Agency (ANVISA) has received a great demand of requests to authorise the commercialisation of specialty oils in capsules in Brazil (VANNUCCHI, 2010). ANVISA aims to ensure that safe and appropriately labelled products are available to the consumers who believe they provide health benefits.

Several studies conducted in Brazil and around the world have showed high incidence of adulteration in vegetable oils, especially olive oil and oils imported with high commercial value (APARICIO, 2003; AUED-PIMENTEL et al., 2008; BECKER et al., 2005).

Among the specialty oils, only fish oils with EPA and DHA have been recognised and registered by ANVISA as products with functional properties. Studies have suggested numerous benefits of omega-3 fatty acids such as prevention of cardiovascular diseases, inflammation, allergies, hypertension, arthritis, some cancers, and multiple sclerosis among others (LIMA et al., 2007; RUIZ-RODRIGUEZ; REGLERO; IBAÑEZ, 2010; SAPIEHA et al., 2011).

Other oils, such as flaxseed, primrose, borage, and safflower are registered as "novel food" (BRASIL, 2008b) when the studies are inconclusive as to their functional properties.

The definition of what constitutes a novel food varies depending on global location or area of interest since some countries have adopted specific terms and definitions (and regulations), while others have not. However, the widely accepted general definition of a novel food is a food or food ingredient that has not been traditionally used as a food. Understanding the regulations for each country will assist companies in putting their novel products and ingredients on the market. The European Union (EU) is one of the most active markets in the area of novel foods, which are defined by the EU as foods and food ingredients that have not been used for human consumption to a significant degree (EUROPEAN..., 2012).

In Brazil, novel foods are regulated by the ANVISA Resolution no 16/1999 (BRASIL, 1999), which does not allow the use the claims of functional properties on the label of this product category. Like in other European countries, in Brazil, companies must submit the product to authorities to get the trade authorization. The companies must present scientific information and the safety assessment report. The product must be safe for consumers and properly labeled to not mislead consumers. In Europe, however, the demands are greater. The risk assessment procedures must be performed before the marketing of novel foods and ingredients. The competent authority decides whether additional assessment is necessary. Before approving, the authority asks the Standing Committee on Food Chain and Animal Health, an expertise committee for an opinion (EUROPEAN..., 2012).

In order to receive ANVISA approval for new food, proof of safety is required. In the process of registration, a technical scientific report containing information such as intended use, recommended intake, scientific description of ingredients, chemical composition with molecular characterization, and product formulation must be submitted. Another requirement is a description of the analytical method used in the evaluation of the food or ingredient for which ANVISA approval is being sought (BRASIL, 1999).

In some countries, like the United States and some European countries, supplements containing conjugated linoleic acid (CLA) with the purpose of body weight reduction are commonly available in the market. Some authors have suggested that ingesting CLA can decrease the size of adipocytes, as well as modify differenciation of adipocytes, by regulating lipid metabolism. But those studies are not conclusive, and randomised controlled trials do not show compelling evidence that the intake of CLA generates clinically relevant effects on body composition in the long term (ONAKPOYA et al., 2012).

CLA has also been shown to exhibit anticarcinogenic properties, as well as a role in immune response modulation and energy metabolism in animal models (FUNCK; BARRERAARELLANO; BLOCK, 2006). CLA is a group of positional and geometric isomers of linoleic acid (18:2) and are found naturally in the fat of ruminant animals. Commercially, CLA isomers can be obtained by alkaline isomerisation and hydrogenation of linoleic acid producing mainly cis 9, trans 11 CLA isomers and trans 10, cis 12 CLA with evidence of health benefits (CHRISTIE; DOBSON; ADLOF, 2007; CARVALHO et al., 2008; RUIZRODRIGUEZ; REGLERO; IBAÑEZ, 2010). However, scientific evidence is not conclusive regarding the efficiency and safety of CLA use (WHIGHAM; WATRAS; SCHOCLLER, 2007). In Brazil, ANVISA has not authorised the sale of oils with CLA (BRASIL, 2007).

General and nutritional information must appear on the labels of oils in capsules commercialized in Brazil, since these products are packaged in the absence of the customer and are ready to be offered to consumers. Brazilian legislation demands the declaration of the total fat, saturated (SFA) and trans (TFA) fatty acid contents on the labels of packaged foods and tolerates $20 \%$ variation between experimental results and the nutrients declared on the label (BRASIL, 2003a).

According to the ANVISA Technical Report nº 36/2008, the serving should be declared in accordance with the provisions of Resolution $\mathrm{n}^{\circ} 360 / 2003$ and labelling aspects of each food specific technical regulation (BRASIL, 2003a, 2008a, b). 
Nutrition declaration should be made by the reference serving of Resolution $n^{\circ} 359 / 2003$ for conventional foods or based on the recommended daily intake specified by the manufacturer of capsules, tablets, pills, and anything similar (BRASIL, 2003b).

Considering the high commercial value, the increasing demand of specialty oils and the detection of adulterated products, it is necessary monitoring these products and ensure the quality to sustain consumer confidence. The present study aimed to evaluate the identity of encapsulated specialty oils commercially available in São Paulo state, Brazil by determining their fatty acids profile [SFA, TFA, mono and polyunsaturated (PUFA)] and the content of Vitamin E (alpha tocopherol) and comparing the results with their nutrition facts label. Special attention was given to monitor the content of gamma-linolenic acid in borage oil, evening primrose, and blackcurrant as well as to detect the presence of CLA in commercial safflower oil.

\section{Materials and methods}

\subsection{Samples}

Twenty one encapsulated specialty oils of 16 different brands were analysed, including eight samples of safflower (Carthamus tinctorius), five of evening primrose oil (Oenothera biennis), six of flaxseed oil (Linum usitatissimum), one of borage oil (Borago officinalis), and one of blackcurrant oil (Riber nigrum). The samples were sent by the Health Surveillance Agency of the State of São Paulo or purchased commercially, and the acquisition was made randomly according to market availability. All samples were within their expiration date (two years). Table 1 shows the type of products, identity code, manufacturing site, mg of oil per capsule and total capsules per bottle, place of acquisition, and price range.

\subsection{Fatty acid determination by gas chromatography analysis}

The contents of SFA, TFA, MUFA, PUFA, 18:2 (linoleic acid), and 18:3 (alpha and gamma-linolenic acid) were evaluated. The methyl esters of fatty acids (FAME) were obtained using the modified method of Hartman and Lago (HARTMAN; LAGO, 1973; INSTITUTO..., 2005) by adding about $100 \mathrm{mg}$ of sample $4 \mathrm{~mL}$ of $0.5 \mathrm{~mol} . \mathrm{L}^{-1}$ sodium hydroxide solution in methanol and $5 \mathrm{~mL}$ of the esterification reagent [ammonium chloride $(10 \mathrm{~g})$ solution in methanol $(300 \mathrm{~mL})$ and sulphuric acid $(15 \mathrm{~mL})]$. The FAME were analysed by gas chromatography with a flame ionization detector (GC-FID) using a Shimadzu equipment model GC17A with a capillary column (CP $7420,100 \mathrm{~m}, 0.25 \mathrm{~mm}, 0.25 \mu \mathrm{m}$, Varian). The optimised chromatographic conditions were the following: programmed column temperature from $45^{\circ} \mathrm{C}$ up to $175^{\circ} \mathrm{C}\left(12{ }^{\circ} \mathrm{C} \cdot \mathrm{min}^{-1}\right)$; then up to $215^{\circ} \mathrm{C}\left(4^{\circ} \mathrm{C} \cdot \mathrm{min}^{-1}\right) ; 215^{\circ} \mathrm{C}$ for 35 minutes; injector and detector temperature: $250^{\circ} \mathrm{C}$; carrier gas: hydrogen; and column pressure: $175 \mathrm{kPa}$. The FAME identity was evaluated by the following standards: mixture of 37 FAME from 4 to 24 carbon atoms (SUPELCO Inc. Bellefonte, PA, USA) with certificated quantities of each compound; mixture of cis/trans FAME isomers of 18:2 (cc, ct, tc, tt) and 18:3 (ccc, cct, $c t t, t c c$, $t t c, t c t, c t c, t t t)$, and FAME standards of CLA (18:2 $9 c, 11 t$ and 18:2 10t, 12c) (Sigma Chemical Co, St Louis, MO). Fatty acids were quantified in triplicate using internal standard FAME 13:0 and 23:0 (Sigma Chemical Co, St Louis, MO, purity > 98\%) (HARTMAN; LAGO, 1973; INSTITUTO..., 2005).

Table 1. Type of products, identity code, manufacturing, place of acquisition, and price range.

\begin{tabular}{|c|c|c|c|c|c|}
\hline Oil description on the label & Identity code & Brand & Manufacturing & mg of oil per capsule (total units) & Price range (US\$) \\
\hline \multirow[t]{6}{*}{ Flaxssed } & $\mathrm{L}^{*}$ & $\mathrm{a}$ & Rio Grande do Sul State, Brazil & $500(60)$ & 3.88 to 39.37 \\
\hline & $\mathrm{L} 2^{* *}$ & $\mathrm{~b}$ & São Paulo State, Brazil & $500(60)$ & \\
\hline & $\mathrm{L}^{* *}$ & c & New York,USA & $1000(60)$ & \\
\hline & $\mathrm{L} 4^{*}$ & $\mathrm{~d}$ & São Paulo State, Brazil & $500(60)$ & \\
\hline & $\mathrm{L}^{*}$ & e & São Paulo State, Brazil & $500(40)$ & \\
\hline & $\mathrm{L} 6^{*}$ & $\mathrm{f}$ & São Paulo State, Brazil & $500(60)$ & \\
\hline \multirow[t]{5}{*}{ Evening primirose } & $\mathrm{P}^{*}$ & a & Rio Grande do Sul State, Brazil & $500(60)$ & 5.58 to 8.98 \\
\hline & $\mathrm{P} 2^{* *}$ & $\mathrm{~b}$ & São Paulo State, Brazil & $500(60)$ & \\
\hline & $\mathrm{P}^{*}$ & g & Rio Grande do Sul State, Brazil & $500(90)$ & \\
\hline & $\mathrm{P} 4^{*}$ & e & São Paulo State, Brazil & $500(90)$ & \\
\hline & $\mathrm{P}^{*}$ & $\mathrm{~h}$ & São Paulo State, Brazil & $500(90)$ & \\
\hline \multirow[t]{8}{*}{ Safflower } & $\mathrm{C} 1^{* *}$ & c & New York,USA & $1000(90)$ & 43.25 to 80.39 \\
\hline & $\mathrm{C} 2^{* *}$ & $\mathrm{i}$ & New York,USA & $1000(90)$ & \\
\hline & $\mathrm{C} 3^{* *}$ & j & São Paulo State, Brazil & $1000(120)$ & \\
\hline & $\mathrm{C}^{* *}$ & $\mathrm{k}$ & São Paulo State, Brazil & $1000(120)$ & \\
\hline & $\mathrm{C} 5^{\star *}$ & 1 & Hollywood, USA & $1000(100)$ & \\
\hline & $\mathrm{C} 6^{* *}$ & $\mathrm{~m}$ & São Paulo State, Brazil & $1000(90)$ & \\
\hline & $\mathrm{C} 7^{*}$ & $\mathrm{n}$ & São Paulo State, Brazil & $1000(90)$ & \\
\hline & $\mathrm{C} 8^{*}$ & o & São Paulo State, Brazil & $1000(120)$ & \\
\hline Borage & $\mathrm{B}^{*}$ & $\mathrm{e}$ & São Paulo State, Brazil & $500(30)$ & 5.57 \\
\hline Blackcurrant & $G^{*}$ & $\mathrm{p}$ & São Paulo State, Brazil & $500(40)$ & 20.70 \\
\hline
\end{tabular}

${ }^{\star}$ Acquired in São Paulo city market. ${ }^{* *}$ Collected by health surveillance of São Paulo state. 
The quality of the results of the analytical procedures was monitored by recovery tests of the internal standards added to the samples in each repetition (FAME 13:0 and 23:0). The area of the standard added (both in the blank and in the samples) was checked, and the FAME 13:0 or 23:0 recovery was calculated. The percentage recovery is expressed through the ratio between experimental and theoretical values.

\subsection{Determination of vitamin E (alpha-tocopherol) by liquid chromatography}

The content of alpha-tocopherol was determined in triplicate by high performance liquid chromatography with a UV-visible detector (HPLC-UV), according to the AOCS official method Ce 8-89 (AMERICAN..., 1998). The oils were dissolved in $\mathrm{n}$-hexane ( 2 to $4 \mathrm{mg} \cdot \mathrm{mL}^{-1}$ ) and submitted directly to chromatographic analysis using a HPLC-UV (Shimadzu) under the following conditions: silica column (Varian, USA, $250 \mathrm{~mm}, 5 \mathrm{~mm}, 4.6 \mathrm{~mm}), \lambda=292 \mathrm{~nm}$, mobile phase (n-hexano/isopropanol, 99.5:0.5 v/v), flow $\left(1.2 \mathrm{~mL} \cdot \mathrm{min}^{-1}\right)$, and quantification with alpha-tocopherol (Sigma Chemical Co, St Louis, MO, purity $>98 \%$ ) as external standard. The quality of the results of the analytical procedures was monitored by analysis of reference samples.

\section{Results and discussion}

The specialty oils in capsules analysed in this study (Table 1) are products registered by ANVISA as novel food. Studies about the functional properties of these products are inconclusive, and functional properties claims on labels are not allowed (BRASIL, $2008 \mathrm{~b}$ ). They can be considered as novel food if there is no history of consumption in the country and are presented as capsules, tablets, or pills. For ANVISA approval for use as food, proof of safety is required (BRASIL, 1999, 2008b).

Table 2 presents the fatty acid composition of all samples including the adulterated ones and the range of genuine vegetable oils for comparison. The results showed that of the six samples of flaxseed oil analysed, three were adulterated (probably with soybean oil), i.e., samples L1, L2, and L4. Of the eight samples of safflower tested, five were adulterated, two probably with soybean oil (samples C3 and C4); one was adulterated with a not clearly identified vegetable oil (C7); and two samples were adulterated with CLA in amounts exceeding $70 \%$ (samples $\mathrm{C} 1$ and $\mathrm{C} 2$ ). Currently, CLA has been prohibited in this type of product by ANVISA (BRASIL, 2007).

Safflower oil, like soybean oil, is rich in linoleic acid (18:2) and can be used in the industrial production of CLA. Considering the economic aspect, in Brazil, safflower oil has a higher commercial value than soybean oil since the former is an imported product. Some studies have shown the beneficial effects of PUFA of safflower oil on energy metabolism and its contribution to reducing body fat (WARDLAW et al., 1991). However, these results can also be observed with the intake of other polyunsaturated oils such as soybean oil (RAMADAN et al., 2009; RUIZ-RODRIGUEZ; REGLERO; IBAÑEZ, 2010).
ANVISA currently prohibits the commercialization of CLA, but it allows the registration and commercialization of safflower oil in the category of novel food. The results obtained in the present study showed that companies have used the name of safflower oil to get the commercialization authorization of illicit products that actually present CLA in their composition. These results should alert regulators to establish stricter criteria for accepting the registration of novel foods (BRASIL, 2008b).

Experimental results indicate the adulteration of one evening primrose oil sample with soybean oil (sample P1) since the content of alpha-linolenic acid was much higher (1.4\%) than the characteristic content of evening primrose oil (less than $0.2 \%$ ) (Table 2).

The samples of evening primrose, borage, and blackcurrant oils contained GLA in the range of a genuine oil: evening primrose seed oil contains 7 to $14 \%$, blackcurrant oil from 14 to $20 \%$, and borage, 17 to $26 \%$. Since it is an omega-6 polyunsaturated fatty acid, GLA is a precursor of essential fatty acids and can help treat various diseases (AUED-PIMENTEL; CARUSO, 1999; FIRESTONE, 2005).

From the evaluation of the fatty acid profiles, it was observed a high incidence of adulteration in commercial specialty encapsulated oils. However, if other more sensitive analytical techniques were used, such as the composition of desmetylsterols or the contents of stadienes, probably, a higher incidence of adulteration would be verified (MATTHÄUS, 2008; BECKER et al., 2005).

The high price of encapsulated specialty oils is associated with different aspects. In most cases, they are imported and cold pressed, and are extracted under low temperature using new and selected raw material.

The oils are extracted on a small scale and require special packaging because they are easily destroyed by heat, light, and oxygen (ESKIN, 2008; CACHPOLE et al., 2009). Packaging (capsules) is an important factor to consider. To avoid peroxidative processes, the packaging should have a good barrier against oxygen, moisture and light radiation. The protection conferred by the package should be higher for more unsaturated lipids (PACHECO; REGITANO-D’ARCE, 2009).

Figures 1 and 2 shows the profiles of FAMEs obtained by GC-FID for authentic flaxseed and safflower (a), respectively, and those adulterated with soybean oil and CLA (b).

Table 3 shows the labelling information of authentic samples (identity code, serving), in addition to the content of SFA, TFA, MUFA, PUFA, linoleic acid (18:2 omega-6), alpha-linolenic acid (18:3 omega-3), gamma-linolenic acid (18:3 omega-6), and alpha-tocopherol expressed in milligrams per serving of oil. The recovering tests of internal standard, FAME 13:0 or 23:0 added to samples (analytical quality of the results) were above $90 \%$. The levels declared on the nutrition label were compared to those obtained by analysis considering the $20 \%$ tolerance range provided by Resolution $n^{\circ} 360 / 2003$ (BRASIL, 2003a).

Several non-compliances were observed: of the 21 samples analysed, only 2 met legislative requirements. Sample L3 (flaxseed oil) contained less than $80 \%$ of linoleic acid than that 


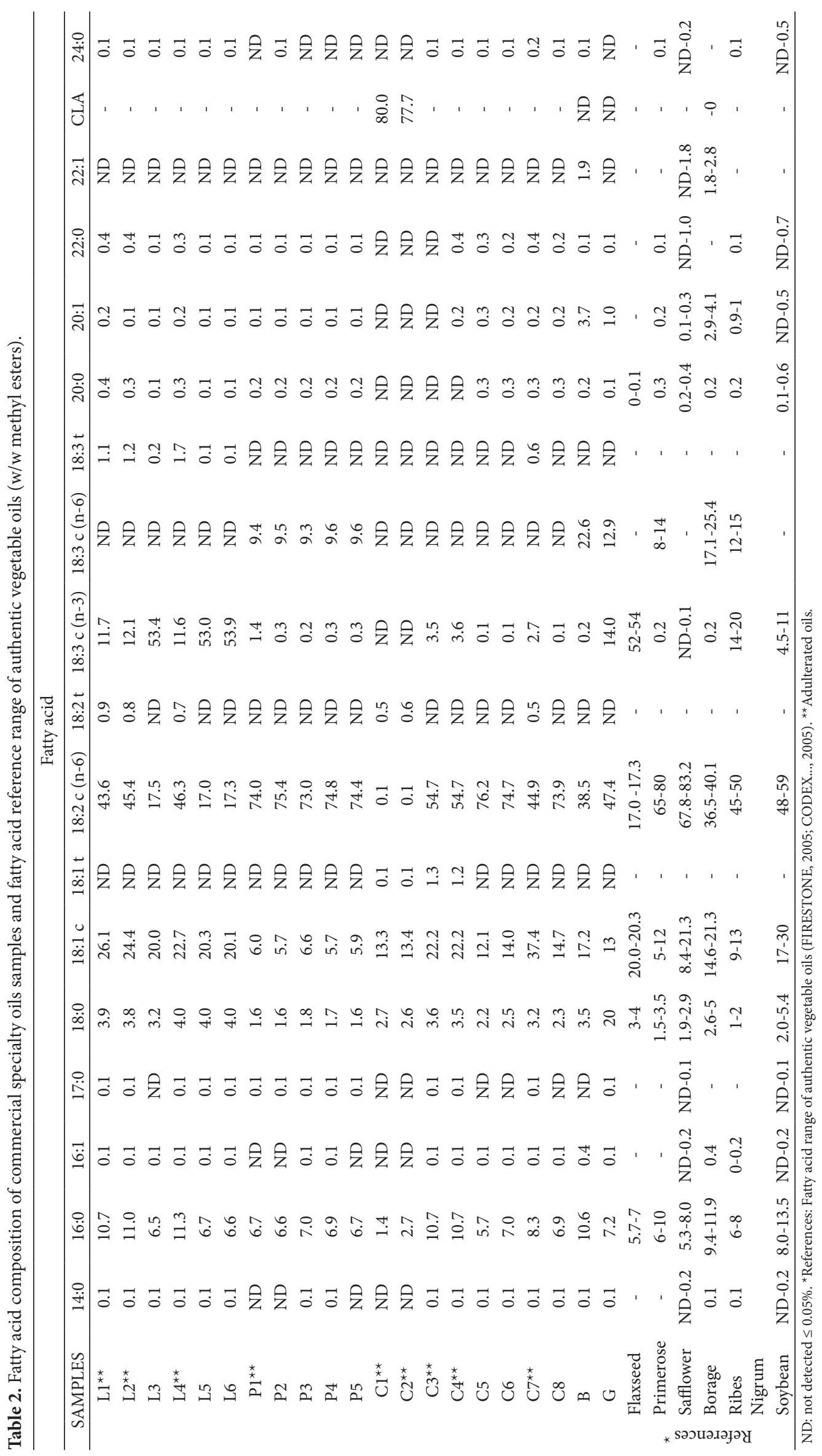




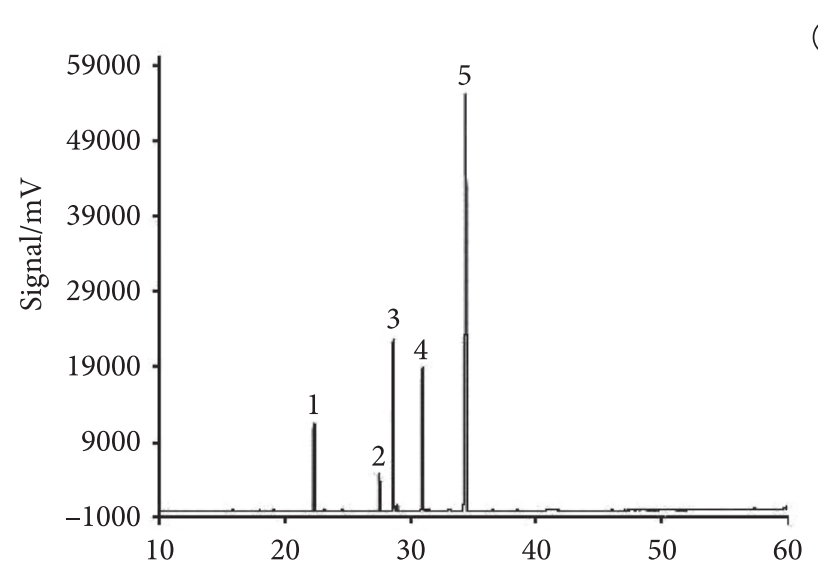

(b)

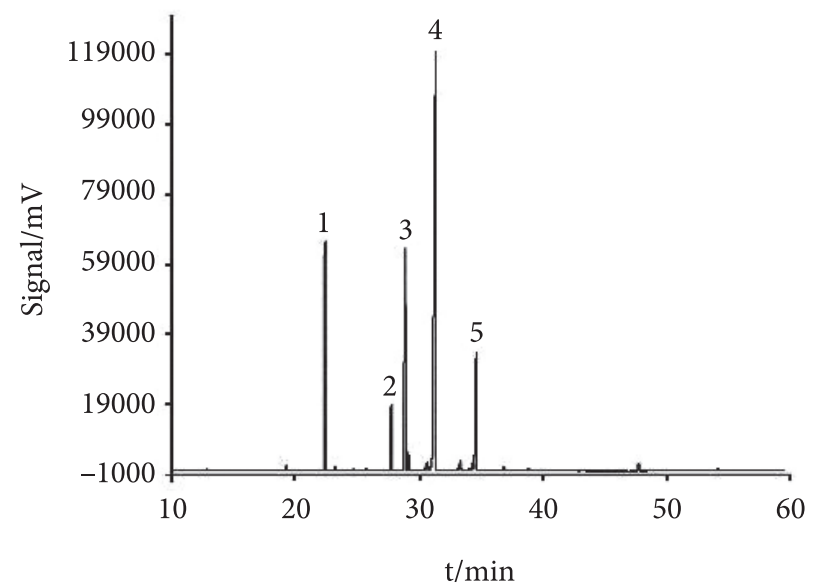

Figure 1. Chromatograms of flaxseed oil. a) Authentic. b) Adulterated (probably with soybean oil). 1. Palmitic acid (16:0); 2 . Stearic acid (18:0); 3. Oleic acid (18:1); 4. Linoleic acid (18:2, 9c,12c); 5. Linolenic acid $(18: 3,9 c, 12 c, 15 c)$.

reported on the label, while sample P2 (evening primrose oil) had levels of PUFA $150 \%$ higher than that declared. The alphatocopherol content in sample $\mathrm{G}$ (blackcurrant oil) was twice as much as that declared on the label. However, the variability of the results obtained in the concentration level in question is within the level shown on the label. The SFA in sample C6 (safflower oil) amounted to 2.3 -fold higher (239\%) than the value declared on the label. Moreover, the authentic oils presented traces of TFA, indicating suitable cold pressed processing.

There was no clarity, consistency, and uniformity with regards to the nutrition information on the labels, especially concerning the size of the serving declared. For example, in the label of sample C6 (safflower oil), it was informed that the package contained 30 servings, but in the nutrition facts label, the recommended serving was $1000 \mathrm{mg}$. However, the package contained 90 capsules of $1000 \mathrm{mg}$, suggesting that the daily serving should be $3000 \mathrm{mg}$ or 3 capsules and not $1000 \mathrm{mg}$.

Sample B (borage oil) presented different sources of nutritional information: one in an outer packaging and one on the product vial. The outer packaging was used for analytical
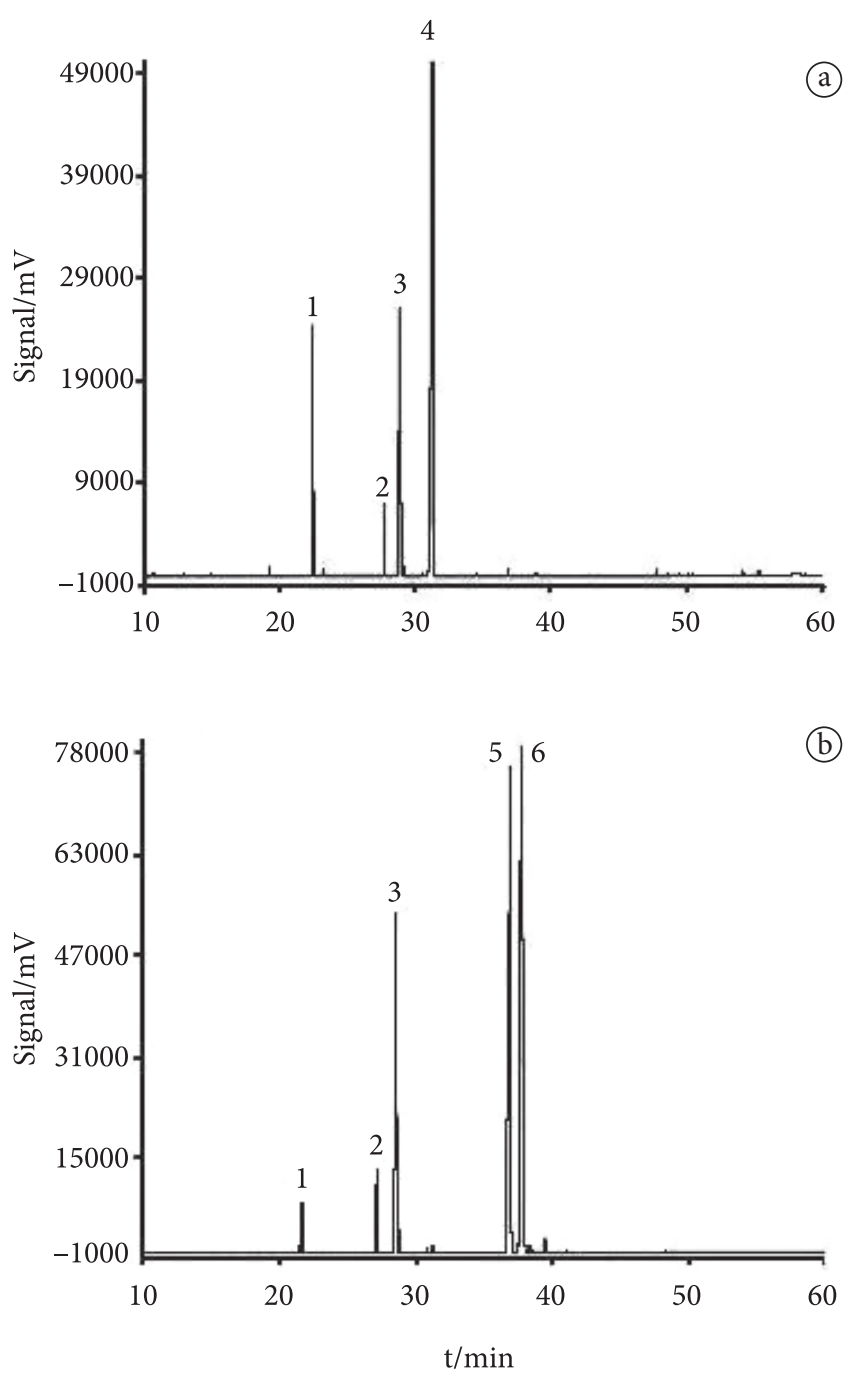

Figure 2. Chromatograms of safflower oil. a) Authentic. b) Adulterated (with conjugated linoleic acid - CLA). 1. Palmitic acid (16:0); 2. Stearic acid (18:0); 3. Oleic acid (18:1); 4. Linoleic acid (18:2, 9c, 12c); 5 . Conjugated linoleic acid $(18: 2,9 c, 11 t) ; 6$. Conjugated linoleic acid $(18: 2,10 t, 12 c)$.

comparison. For this same sample, there was a mistake in the information on the label. The name of linoleic acid was replaced with linolenic acid with the omega- 6 series. Nevertheless, it should be noted that linoleic acid belongs to that series.

For the samples with contents of SFA and TFA below $200 \mathrm{mg}$ per serving $(0.2 \mathrm{~g})$, the manufacturer can express them as zero on the nutrition label (BRASIL, 2003a). This was the case for samples L3, B, G, and C5. Samples P2 and C6, despite showing values for TFA on the label, had levels below $200 \mathrm{mg}$ and therefore, the content in these samples should also be expressed as zero. Such evidence may be considered good for the consumer, since they can know the exact contents of this component, which if consumed at high levels can be harmful to health.

Sample P5 was commercialized without nutritional information on the label. It was purchased at a drugstore. 
Hirashima et al.

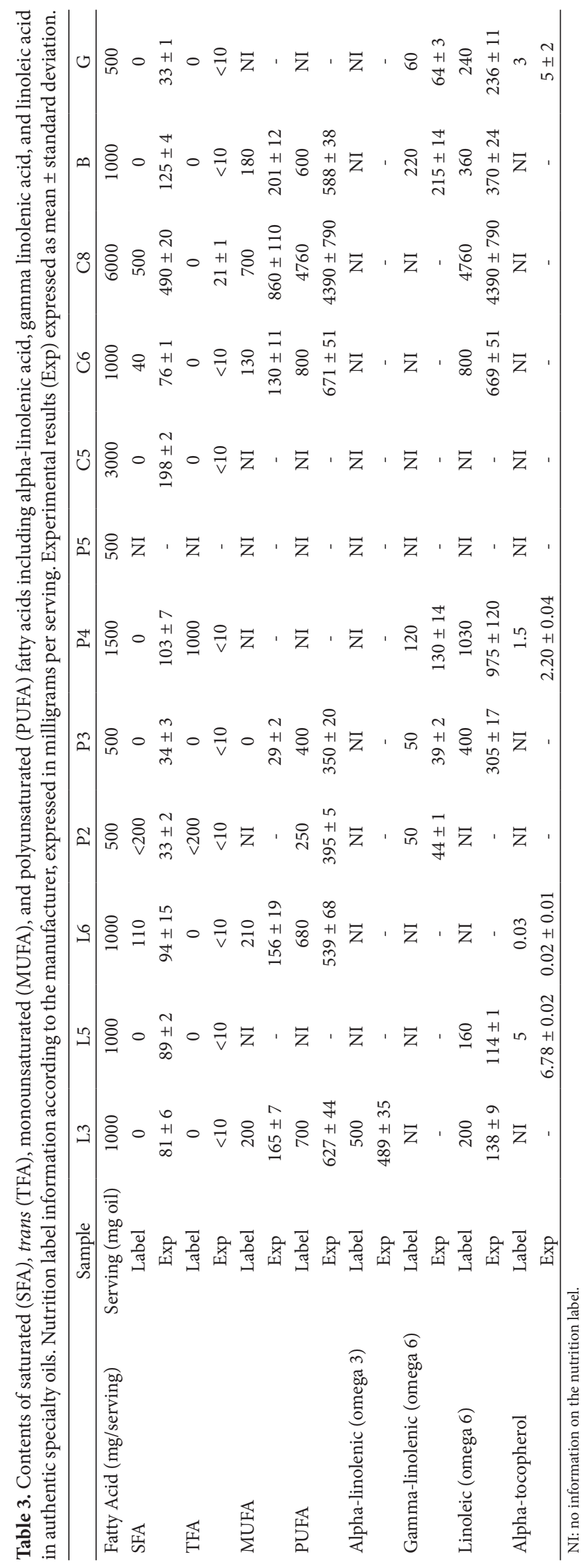


Although the encapsulated primrose oil is sold in a drugstore, it must meet the mandatory nutritional labeling legislation since it is registered by ANVISA as a food product. This is an example that shows a common practice in the trade of these products. The consumer, for whom the product is intended, often does not know the legal requirements for the sale of some products they acquire in commerce. Once again, the consumer's right to accurate information about the reliable information has not been protected.

\section{Conclusions}

Despite the requirements in the registration process of novel foods in Brazil, this study showed a high incidence of adulteration in the products analysed (about 40\%). Only two samples, of the twenty one samples evaluated, met legislative requirements for nutritional labeling information of SFA, MUPA, PUFA, and TFA. The remaining samples were not in compliance with the regulations regarding at least one of the items evaluated. The high commercial value of these products and the lack of supervisory and regulatory practices favour adulteration. The use of more sensitive analytical techniques would perhaps detect a higher level of adulteration in the commercial samples.

The results indicate the need for enhanced monitoring including a larger number of samples in conjunction with enforcement actions by the Health Surveillance Agency. The present study also indicates the need to review the ANVISA acceptance criteria for registration of specialty oils in capsules, especially those categorised as novel food. Like in European countries, in Brazil, risk assessment procedures should be performed before the marketing of novel foods and ingredients. Before approving, the competent authority with the help of an expertise committee should decide whether additional assessment of purity and identity are necessary. These actions will help protect the right of consumers to purchase safe food.

\section{Acknowledgements}

The authors acknowledge the fellowship provided by CNPQ to the first author.

\section{References}

AMERICAN OIL CHEMISTS' SOCIETY - AOCS. Official Methods and Recommended Practices of the American Oil Chemists' Society. Chicago, 1998. Method Ce 8-89.

APARICIO, R. Autenticación del aceite de oliva. In: APARÍCIO, R.; HARWOOD, J. Manual del aceite de oliva. Madri: Ediciones Mundi-Prensa, 2003. 614 p.

AUED-PIMENTEL, S.; CARUSO, M. S. F. Ácido gama-linolênico: fontes e perspectivas de sua aplicação terapêutica. Boletim do SBCTA, v. 33, p. 162-166, 1999.

AUED-PIMENTEL, S. et al. Determinação da diferença entre o valor real e o teórico do triglicerídeo ECN 42 para a detecção de adulteração em azeites de oliva comercializados no Brasil. Química Nova, v. 31, n. 1, p. 31-34, 2008. http://dx.doi.org/10.1590/S010040422008000100006
BECKER, D. F. S. et al. Quantificação de fitosteróis em azeite de oliva importados e disponíveis no comércio de Campinas utilizando cromatografia em fase gasosa. Brazilian Journal of Food Technology, v. 8, p. 190-199, 2005.

BRASIL. Ministério da Saúde. Agência Nacional de Vigilância Sanitária. Informe técnico $n^{\circ} 36$, de 27 de junho de 2008. Orientações sobre a declaração da informação nutricional em alimentos para fins especiais e outras categorias específicas. Diário Oficial da República Federativa do Brasil, Brasília, DF, jun. 2008a. Disponível em: <http://www.anvisa.gov.br/alimentos/informes/36_270608. htm>. Acesso em: 2 set. 2008.

BRASIL. Ministério da Saúde. Agência Nacional de Vigilância Sanitária. Alimentos com Alegações de Propriedades Funcionais e ou de Saúde, Novos Alimentos/Ingredientes, Substâncias Bioativas e Probióticos. Lista de alegações de propriedade funcional aprovadas. Brasília, 2008b. Disponível em: <http://www.anvisa. gov.br/alimentos/comissoes/tecno_lista_alega.htm>. Acesso em: 2 set. 2008.

BRASIL. Ministério da Saúde. Secretaria de Vigilância Sanitária. Resolução-RDC no 16, de 30 de abril de 1999. Aprova o Regulamento Técnico de Procedimentos para Registro de Alimentos e ou Novos Ingredientes. Diário Oficial da República Federativa do Brasil, Brasília, DF, 03 dez. 1999. Disponível em: <http://www.anvisa.gov. br/legis/resol/16_99.htm>. Acesso em: 3 mai. 2011.

BRASIL. Ministério da Saúde. Secretaria de Vigilância Sanitária. Resolução-RDC no 360, de 23 de dezembro de 2003. Aprova o Regulamento Técnico sobre Rotulagem Nutricional de Alimentos Embalados, tornando obrigatória a rotulagem nutricional. Diário Oficial da República Federativa do Brasil, Brasília, DF, 26 dez. 2003a. Disponível em: <http://www.anvisa.gov.br/legis/ resol/2003/rdc/360_03rdc.htm>. Acesso em: 12 jun. 2011.

BRASIL. Ministério da Saúde. Secretaria de Vigilância Sanitária. Resolução-RDC no 359, de 23 de dezembro de 2003. Aprova o Regulamento Técnico de Porções de Alimentos Embalados para Fins de Rotulagem Nutricional. Diário Oficial da República Federativa do Brasil, Brasília, DF, 26 dez. 2003b. Disponível em: <http://www.anvisa.gov.br/legis/resol/2003/rdc/359_03rdc.htm>. Acesso em: 12 jun. 2011.

BRASIL. Ministério da Saúde. Agência Nacional de Vigilância Sanitária. Resolução-RE no 833, de 28 de março de 2007. Determina a apreensão, em todo território nacional, de todos os lotes do produto Ácido Linoleico Conjugado - CLA, por não possuir registro no Ministério da Saúde. Diário Oficial da República Federativa do Brasil, Brasília, DF, 29 mar. 2007. Disponível em: <http://www. anvisa.gov.br/divulga/noticias/"as"as2007/re_833_07.pdf>. Acesso em: 20 jun. 2011.

CACHPOLE, O. J. et al. The extraction and fractionation of specialty lipids using near critical fluids. Journal of Supercritical Fluids, v. 47, p. 591-597, 2009. http://dx.doi.org/10.1016/j.supflu.2008.10.008

CARVALHO, E. B. T. et al. Avaliação in vitro da atividade antioxidante dos isômeros do ácido linoleico conjugado. Revista Brasileira de Ciências Farmacêuticas, v. 44, 2008. Supplement. Program and abstract in XIII Semana Farmacêutica de Ciência e Tecnologia, 2008, São Paulo/SP, Brazil.

CHRISTIE, W. W.; DOBSON, G.; ADLOF, R. O. A practical guide to the isolation, analysis and identification of conjugated linoleic acid. Lipids, v. 42, p. 1073-1084, 2007. PMid:17710464. http://dx.doi. org/10.1007/s11745-007-3107-8

CODEX ALIMENTARIUS COMMISSION. Codex Standards for named vegetable Oils. Rome: Codex Alimentarius, 2005. Codex Stan 210 (Amended 2003, 2005). 
ESKIN, N. A. M. Borage and evening primrose oil. European Journal of Lipid Science and Technology, v. 110, p. 651-654, 2008. http:// dx.doi.org/10.1002/ejlt.200700259

EUROPEAN COMMISSION. DG Health and Consumers. Overview. Food and Feed Safety. In: EUROPEAN COMMISSION. Health and consumers. Novel foods and novel food ingredients. 2012. Disponível em: <http://ec.europa.eu/food/food/biotechnology/ novelfood/index_en.htm>. Acesso em: 4 set. 2012.

FIRESTONE, D. Physical and chemical characteristics of oils, fats and waxes. Champaign: AOCS Press, 2005.

FOSTER, R. H.; HARDY, G.; ALANY, R. G. Borage oil in the treatment of atopic dermatitis. Nutrition, v. 26, p. 708-718, 2010. PMid:20579590. http://dx.doi.org/10.1016/j.nut.2009.10.014

FUNCK, L. G.; BARRERA-ARELLANO, D.; BLOCK, J. M. Ácido linoléico conjugado (CLA) e sua relação com a doença cardiovascular e os fatores de risco associados. Archivos Latinoamericanos de Nutrición, v. 57, p. 123-134, 2006.

HARTMAN, L.; LAGO, R. C. A. Rapid preparation of fatty acid methyl esters from lipids. Laboratory Practice, v. 22, n. 8, p. 475-476, 1973. PMid:4727126.

HOMYEH, A. et al. The effect of gamma-linolenic acid on plasma and membrane lipids and renal prostaglandin synthesis in older subjects. Bratislavské Lekárske Listy, v. 103, p. 101-107, 2002.

INSTITUTO ADOLFO LUTZ - IAL. Métodos físico-químicos para análise de alimentos. 4. ed. Brasília: ANVISA, 2005. 1018 p.

KATSIKI, N.; MANES, M. Is there a role for supplemented antioxidants in the prevention of atherosclerosis? Clinical Nutrition, v. 28, p. 3-9, 2009. PMid:19042058. http://dx.doi.org/10.1016/j. clnu.2008.10.011

KONG, X. et al. Gamma-linolenic acid modulates the response of multidrug-resistant K562 leukemic cells to anticancer drugs. Toxicology in Vitro Journal, v. 23, p. 634-639, 2009. PMid:19268700. http://dx.doi.org/10.1016/j.tiv.2009.02.010

LIMA, T. M. et al. Ácidos graxos e saúde. In: Simpósio sobre ácidos graxos e saúde, 3., 2007, São Paulo. Anais... São Paulo, 2007.

MARTEN, B.; PFEUFFER, M.; SCHREZENMEIR, J. Medium-chain triglycerides. International Dairy Journal, v. 16, p. 1374-1382, 2006. http://dx.doi.org/10.1016/j.idairyj.2006.06.015

MATTHÄUS, B. Virgin grape seed oil: Is it really a nutritional highlight? European Journal of Lipid Science and Technology, v. 110, p. 645-650, 2008. http://dx.doi.org/10.1002/ejlt.200700276

NEVIN, K. G.; RAJAMOHAN, T. Beneficial effects of virgin coconut oil on lipid parameters and in vitro LDL oxidation. Clinical Biochemistry, v. 37, p. 830-835, 2004. PMid:15329324. http:// dx.doi.org/10.1016/j.clinbiochem.2004.04.010

ONAKPOYA, I. J. et al. The efficacy of long-term conjugated linoleic acid (CLA) supplementation on body composition in overweight and obese individuals: a systematic review and meta-analysis of randomized clinical trials. European Journal of Nutrition, v. 51, n. 2, p. 127-134, 2012. PMid:21990002. http://dx.doi.org/10.1007/ s00394-011-0253-9

PACHECO, S. G. A.; REGITANO-D’ARCE, M. A. R. Estabilidade oxidativa de óleo de peixe encapsulado em diferentes tipos de embalagem em condição ambiente. Ciência e Tecnologia de Alimentos, v. 29, p. 927-932, 2009. http://dx.doi.org/10.1590/ S0101-20612009000400034

PHAM, H.; VANG, K.; ZIBOH, V. A. Dietary gamma-linolenate attenuates tumor growth in a rodent model of prostatic adenocarcinoma via suppression of elevated generation of PGE(2) and 5S-HETE. Prostaglandins Leukot Essent Fatty Acids, v. 74, n. 4, p. 271-282, 2006. PMid:16567086. http://dx.doi.org/10.1016/j. plefa.2006.01.004

RAMADAN, M. F. et al. Changes in lipid profile by vegetable oil blends rich in polyunsaturated fatty acids in rats with hypercholesterolemia. Food Science and Technology International, v. 15, p. 119-130, 2009. http://dx.doi.org/10.1177/1082013208105167

RUIZ-RODRIGUEZ, A.; REGLERO, G.; IBAÑEZ, E. Recent trends in the advanced analysis of bioactive fatty acids. Journal of Pharmaceutical and Biomedical Analysis, v. 51, p. 305-326, 2010. PMid:19525080. http://dx.doi.org/10.1016/j.jpba.2009.05.012

SAPIEHA, P. et al. 5-Lipoxygenase metabolite 4-HDHA is a mediator of the antiangiogenic effect of $\omega-3$ polyunsaturated fatty acids. Science Translational Medicine, v. 3, p. 1-12, 2011. PMid:21307302. http:// dx.doi.org/10.1126/scitranslmed.3001571

SIMPOULOS, A. P. Evolutionary aspects of diet the omega6/omega3 ratio and genetic variation: nutritional implications for chronic diseases. Biomedicine \& Pharmacotherapy, v. 60, p. 502-507, 2006. PMid:17045449. http://dx.doi.org/10.1016/j.biopha.2006.07.080

SOUZA, P. H. M.; SOUZA-NETO, M. H.; MAIA, G. A. Componentes funcionais nos alimentos. Boletim do SBCTA, v. 37, p. 127-135, 2003.

VANNUCCHI, H. Alimentos Funcionais. In: SIMPÓSIO BRASILEIRO DE SEGURANÇA ALIMENTAR, 3., 2010, Florianópolis. Anais... Florianópolis, 2010.

WARDLAW, G. M. et al. Serum lipid and apolipoprotein concentrations on healthy men on diets enriched in either canola oil or safflower oil. American Journal of Clinical Nutrition, v. 54, p. 104-110, 1991. PMid:1905474.

WHIGHAM, L. D.; WATRAS, A. C.; SCHOCLLER, D. A. Efficacy of conjugated linoleic acid for reducing fat mass: a meta-analysis in humans. American Journal of Clinical Nutrition, v. 85, p. 1203-1211, 2007. PMid:17490954.

YOSHIDA, H.; KISUGI, R. Mechanisms of LDL oxidation. Clinica Chimica Acta, v. 411, p. 1875-1882, 2010. PMid:20816951. http:// dx.doi.org/10.1016/j.cca.2010.08.038 